\title{
Carotenoid contents during ripening of banana hybrids and cultivars grown in Cameroon
}

\author{
Gérard NGOH NeWILAH ${ }^{1 *}$, Claudie Dhuique-MAYeR ${ }^{2}$, Juan RoJAS-GonZALEZ ${ }^{2}{ }_{1}$ Kodjo ToMeKPEE $^{1}$, Elie Fokou ${ }^{3}$, François X. EtoA ${ }^{3}$
}

${ }^{1}$ Cent. Afr. Rech. Banan. Plantains, Njombé, BP 832, Douala, Cameroon gbngoh@yahoo.com

2 UMR 95, Integr. Food Process. Res. Unit, CIRAD, Persyst, TA B-95 / 16, 34398 Montpellier Cedex 5, France

${ }^{3}$ Dep. Biochem., Univ. Yaoundé I, BP 812, Yaoundé, Cameroon

* Correspondence and reprints

Received 4 August 2008 Accepted 9 February 2009

Fruits, 2009, vol. 64, p. 197-206 (C) 2009 Cirad/EDP Sciences All rights reserved DOI: $10.1051 /$ fruits/2009015 www.fruits-journal.org

RESUMEN ESPAÑOL, p. 206

\section{Carotenoid contents during ripening of banana hybrids and cultivars grown in Cameroon.}

Abstract - Introduction. Bananas and plantains (Musa spp.) are staple foods in Cameroon and surrounding countries. Strategies based on the utilization of cultural and locally consumed foods are essential for the identification of solutions for the reduction of micronutrient malnutrition. Materials and methods. To assess the nutritional content of some varieties in order to assist the selection of new Musa hybrids, the carotenoid contents of 19 Musa cultivars and hybrids from the CARBAP (Douala, Cameroon) germplasm were determined at three ripening stages. Frozen pulps were analyzed for their $\beta$-carotene, $\alpha$-carotene and lutein contents using the HPLC method. The retinol activity equivalents (RAE) $100 \mathrm{~g}^{-1}$ fresh weight were calculated for four representative Musa types. Results and discussion. Significant differences were observed between Musa cultivars according to their genotype. Plantain type (Mbouroukou $\mathrm{n}^{\circ}$ ) and Musa hybrid (CRBP 755) exhibited the highest levels of RAE [(148 and 70) RAE $100 \mathrm{~g}^{-1}$ ] compared with dessert bananas (16 RAE $\left.100 \mathrm{~g}^{-1}\right)$. During ripening, the concentrations of these carotenoids increased or decreased significantly $(\alpha=0.05 \%)$ according to the Musa type analyzed. The high $\beta$ - and $\alpha$-carotene as well as lutein contents of these Musa sp. could contribute to the nutritional status of people consuming these banana varieties in West and Central Africa and enhance their use in Musa breeding programs.

\section{Cameroon / Musa / fruits / ripening / developmental stages / carotenoids}

\section{Teneur en carotenoïdes pendant la maturation d'hybrides et de cultivars de bananes, cultivés au Cameroun.}

Résumé - Introduction. Les bananes et les plantains (Musa spp.) sont des aliments de base au Cameroun et dans les pays environnants. Des stratégies basées sur l'utilisation d'aliments de culture et de consommation locales sont essentielles pour l'identification de solutions visant à réduire le manque d'oligoéléments dans la nutrition. Matériel et méthodes. Pour évaluer la valeur alimentaire de quelques variétés de bananes afin d'aider au choix de nouveaux hybrides de Musa, les teneurs en caroténoïdes de 19 cultivars et hybrides du genre Musa présents dans la collection de matériel génétique du CARBAP (Douala, Cameroun) ont été déterminées à trois stades de maturation postrécolte. Des pulpes congelées ont été analysées pour leurs teneurs en $\beta$-carotène, $\alpha$-carotène et lutéine en utilisant la méthode HPLC. Les équivalents d'activité du rétinol (EAR $100 \mathrm{~g}^{-1}$ de matière fraîche) ont été calculés pour quatre types représentatifs de Musa. Résultats et discussion. En fonction des génotypes, on a observé des différences significatives parmi les cultivars de Musa; Mbouroukou nº1 (type plantain) et l'hybride CRBP 755 ont présenté les niveaux d'EAR les plus élevés [(148 et 70) EAR $100 \mathrm{~g}^{-1}$ ] comparés aux valeurs mesurées pour les bananes dessert $\left(16 \mathrm{EAR} \cdot 100 \mathrm{~g}^{-1}\right)$. Pendant la maturation, les concentrations des carotenoïdes ont augmenté ou diminué de manière significative $(\alpha=0.05 \%)$ selon le type de banane analysé. Les fortes teneurs en $\beta$-carotène, $\alpha$-carotène et lutéine de ces cultivars pourraient contribuer à améliorer le statut nutritionnel des personnes qui les consomment en Afrique centrale et occidentale et encourager leur utilisation dans des programmes d'amélioration variétale du bananier.

Cameroun / Musa / fruits / maturation / stade de développement / caroténoïde 


\section{Introduction}

Carotenoids are notable for their wide distribution, structural diversity and various functions. Those in foods are generally $\mathrm{C}_{40}$ tetraterpenoids formed from eight $\mathrm{C}_{5}$ isoprenoids head-to-tail, except at the center, where a tail-to-tail linkage reverses the order, resulting in a symmetrical molecule. Hydrocarbon carotenoids are known as carotenes, and oxygenated derivatives are called xanthophylls [1]. Carotenoids are present in fruits, vegetables and other crops and they are also found in algae, bacteria, yeast and fungi $[2,3]$. Provitamin A carotenoids, most importantly beta-carotene, followed by alpha-carotene, are those which are converted into vitamin $\mathrm{A}$ in the body and help protect against infection, night blindness and eye disease. Another important carotenoid with demonstrated health benefits is lutein. In nature about $100 \mathrm{Mt}$ of these compounds are produced annually [4]. Carotenoid-rich foods, whether with vitamin A activity or not, have been credited with other beneficial effects on human health: enhancement of the immune response and reduction of the risk of degenerative diseases such as cancer, cardiovascular diseases, cataracts and macular degeneration [5-12]. The biological action of carotenoids against diseases has been attributed to an antioxidant property; specifically, their ability to quench singlet oxygen and interact with free radicals [13].

In carotenogenic fruits and fruit vegetables, ripening is usually accompanied by enhanced carotenogenesis as chlorophylls decompose and the chloroplasts are transformed into chromoplast. Increased carotenogenesis with maturation has been documented in Mormordica charantia, yellow Lauffener gooseberry, red pepper, badami mango, etc. In fruits in which the color at the ripe stage is due to anthocyanins (yellow cherry, red currant, strawberry) and in fruits that retain their green color when ripe (kiwi), the carotenoid concentrations decrease with ripening. The one factor that decisively affects the carotenoid content is the maturity of the plant food when harvested and offered for consumption [14].

Bananas and plantains are grown in more than 120 countries in the tropical and sub- tropical regions of the world, mainly for their fruits, as well as for their leaves and fibers. Generally, banana and plantain varieties are characterized by different yellow and orange shades of flesh coloration when ripe. In Cameroon, their production has been estimated at $2.26 \mathrm{Mt}$ per annum ${ }^{1}$. Strategies based on the utilization of cultural and locally consumed foods are essential for the identification of solutions for the reduction of micronutrient malnutrition in Cameroon and other countries. Micronutrient malnutrition constitutes a major health problem in sub-Saharan Africa. In Cameroon, the national vitamin A deficiency (VAD) survey conducted in 2000 revealed that $40 \%$ of children were vitamin A-deficient (serum retinol concentration $<0.70 \mathrm{mmol} \cdot \mathrm{L}^{-1}$ ) [15]. Vitamin A deficiency affects more than $250 \mathrm{M}$ children below 5 years old in the world. Most compellingly, the region exhibits one of the highest rates of clinical or severe subclinical vitamin A deficiency (VAD) and mortality in children under 5 years of age (seven out of the top ten countries with the highest under-five-years mortality rates are in West and Central Africa) according to the UNICEF State of the World's Children report in 2005 [16].

Our study was carried out in order to determine the carotenoid contents during ripening of some dessert and cooking bananas, plantain cultivars and Musa hybrids produced in the African Research Center on Bananas and Plantains, in Njombé, Cameroon. This was achieved by considering the general nutritional aspect of carotenoids, and specifically their provitamin A activity. Also, the aim of our study was defined knowing that bananas and plantains are major staple food crops for millions of people in West and Central Africa where they contribute significantly to food security, and due to the need for a better utilization of these plants in human nutrition and Musa breeding.

1 www.fao.org. Cameroon production of bananas and plantains in 2006, in: Food Agric. Organ. Stat. Div. 2008, http://faostat.fao.org/site/567/DesktopDefault.aspx? PageID $=567$, seen on June 2008. 


\section{Materials and methods}

We studied ten plantain cultivars (Essong, French clair, French sombre, Kelong mekintu, Red Yade, Big Ebanga, Mbouroukou $n^{\circ} 1$, Mbouroukou $n^{\circ} 3$, Bâtard and Biya 2), three cooking bananas (Dwarf kalapua, Laknau and Popoulou CMR) and three dessert bananas (Foconah, Grande Naine and Yangambi km 5), as well as three Musa hybrids (DS 11, CRBP 39 and CRBP 755). The main Musa varieties consumed in some regions of Cameroon were thus considered [17].

Bunches were harvested from an experimental plot settled in CARBAP. Fruits from the second and third hands were detached from the stalk and put in the same cardboard box before being mixed so as not to identify more fruits of the 2 nd or 3 rd hand. Thereafter, they were randomized, collected, then sorted into three stages of maturation according to the external color of the peel [18]: full green (initial or stage 1), yellow with green ends (ripe or stage 5) and entirely yellow with black spots (fully ripe or stage 7). Samples were thus grouped because physicochemical analysis of some bananas and plantains during ripening showed and confirmed that generally these peel colors indicate the ripeness of the flesh well [19, 20] although, in a few Musa varieties, the flesh may be ripe when the peel appears to be still green/unripe.

\subsection{Sample preparations}

About $50 \mathrm{~g}$ of quartered fresh pulps from two chosen fruits of the second and third hands were electrically sealed in polyethylene bags after air removal through simple aspiration and kept frozen at $-20^{\circ} \mathrm{C}$. These samples were stored for between (3 and 5) months prior to analysis. The frozen pulps, still in polyethylene bags entirely covered with ice blocks in a cool box/ice chest, were transported by airmail to CIRAD in Montpellier, France, for further carotenoid analyses. It should be noted that the samples arrived in the laboratory completely in a frozen condition for unripe pulps and about $80 \%$ frozen for ripe pulps.

\subsection{Extraction, and qualitative and quantitative analysis}

Reference compounds were from Extrasynthèse (Genay, France) and reagents as well as all solvents, which were of the highest analytical grade, were from Sigma-Aldrich Chimie (Saint-Quentin Fallavier, France).

\subsubsection{Carotenoid extraction}

At least three frozen samples of the same variety were quartered and $15 \mathrm{~g}$ were pulverized for $3 \mathrm{~min}$ in liquid nitrogen with a Dangoumeau 300-ball mill (Prolabo, France). Carotenoid extraction was adapted from the method of Kimura and Rodriguez-Amaya [21]. Tert-butyl-methyl-phenol $(0.1 \% \mathrm{v} / \mathrm{v})$ was added to all the extraction and HPLC solvents. Under red light, powdered samples [(2-5) g] were mixed for $10 \mathrm{~min}$ in a glass tube with $15 \mathrm{~mL}$ of acetone and $150 \mathrm{mg}$ of magnesium carbonate to neutralize acids. The mixture was then filtered with a sintered glass funnel (porosity 3 or 4 ). This operation was repeated thrice, until the residue was colorless. The filtrate was transferred to a separatory glass funnel containing $15 \mathrm{~mL}$ petroleum ether for partition. The mixture was washed once with 10\% sodium chloride and several times (3-5) with distilled water; the aqueous layer was discarded after 3 min of partition. The petroleum layer was then concentrated in a rotary evaporator at $32{ }^{\circ} \mathrm{C}$

\subsubsection{Carotenoid analysis}

Carotenoids were analyzed according to an already published method [22]. The residue was dissolved in $1 \mathrm{~mL}$ [dichloromethane:tertmethyl-buthyl-ether:methanol] (50:40:10, $\mathrm{v} / \mathrm{v} / \mathrm{v})$. Samples were filtered through a 0.45- $\mu \mathrm{m}$ polyvinylidenedifluoride (PVDF) filter and injected immediately into HPLC. The carotenoid analysis was performed with an Agilent 1100 series chromatograph. The column was a polymeric YMC-30 $(250 \mathrm{~mm} \times$ $4.6 \mathrm{~mm}, 5 \mu \mathrm{m}$ particle size, YMC Inc., Wilmington NC) thermostated at $25^{\circ} \mathrm{C}$, and the mobile phase was composed of distilled water, methanol and tert-methyl-buthylether at a flow rate of $1 \mathrm{~mL} \cdot \mathrm{min}^{-1}$. A gradient was applied from (40:60:0) to $(4: 81: 15)$ 
Figure 1.

Chromatogram of fully ripe pulp of Kelong Mekintu (Musa, Plantain type, AAB) in Cameroon.

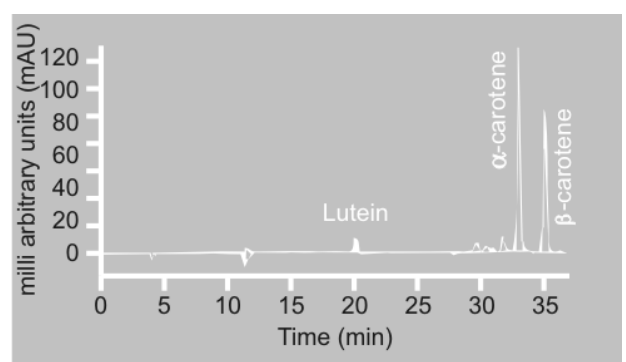

$(\mathrm{v} / \mathrm{v} / \mathrm{v})$ over $10 \mathrm{~min}$, then from $(4: 81: 15)$ to $(4: 11: 85)(\mathrm{v} / \mathrm{v} / \mathrm{v})$ over $50 \mathrm{~min}$ until the end of the run. A UV-visible photodiode array detector was used and chromatographs were analyzed at the wavelength of maximum absorption of the carotenoids in the mobile phase $(\lambda=450 \mathrm{~nm})$. Carotenoids were identified according to their characteristic absorption spectra, and by comparing their retention times with a reference standard alpha+beta-carotene mixture, beta-carotene and lutein (Extrasynthese-GenayFrance). Quantification of carotenoids was achieved using calibration curves with $\beta$-carotene. The results were expressed in $\mu \mathrm{g} \beta$-carotene equivalent per $100 \mathrm{~g}$ on a dry matter basis

\subsubsection{Vitamin A value}

Based on fresh weight, the vitamin A value was calculated as retinol activity equivalent (RAE), using the following conversion: $\mathrm{RAE}=(\mu \mathrm{g}$ of $\beta$-carotene $/ 12)+(\mu \mathrm{g}$ of $\alpha$-carotene/24).

\subsection{Statistical analysis}

For the same variety, three frozen samples from three different bunches were submitted to carotenoid extraction and analyses were performed in triplicate. ANOVA and mean comparisons by the SNK test $(P \leq 0.05)$ were performed with the general linear model procedure of SAS statistical software (version 8.2 for Windows) [23].

\section{Results and discussion}

The chromatograms of the Musa pulps analyzed at three post-harvest maturity stages showed that the principal carotenoids were $\beta$-carotene, $\alpha$-carotene and lutein, the first two nutrients being the major banana and plantain carotenoids (figure 1).

The $\alpha$-carotene levels of unripe pulps of all the Musa analyzed were higher than those of lutein and $\beta$-carotene for the same variety, except for Dwarf kalapua. Also, Yangambi km 5 exhibited a higher value of lutein compared with the $\beta$ - and $\alpha$-carotene levels. At this maturity stage, Mbouroukou $\mathrm{n}^{\circ} 1$ and Bâtard exhibited the highest values, which was not observed during the ripening process of the 19 cultivars studied (tables IIII). The amount of $\alpha$-carotene decreased considerably from stage 1 to stage 7 for the plantains, and varied (increasing or decreasing according to the variety) during postharvest maturation of bananas and plantain hybrids. These changes are not often significantly different. However, samples were not prepared using vacuum sealing, but air removal in polyethylene bags prior to sealing was done through simple aspiration for all the samples whether unripe, starting to be ripe, ripe or fully ripe pulps and stored in the same conditions. It is likely that a little oxidation may have taken place during storage. The $\alpha$-carotene contents in raw pulps of hybrids and some plantain cultivars, as well as of the banana varieties analyzed are, respectively, higher than and similar to those (42-383 $\mu \mathrm{g} \cdot 100 \mathrm{~g}{ }^{1}{ }^{1}$ of edible portion) of Micronesian bananas, in which $\beta$-carotene levels are higher than those of $\alpha$-carotene [24].

$\beta$ - and $\alpha$-carotene concentrations of Yangambi km 5 were very low at all the stages of maturity studied. The unripe pulps of Bâtard and Mbouroukou n ${ }^{\circ} 1$ still showed the highest $\beta$-carotene contents. They varied significantly during their post-harvest maturation; the maximum values were always obtained with unripe and, sometimes, with ripe pulps compared with fully ripe pulps (table II). In plantain, evidence suggests that the yellowing of the fruit pulp during ripening is caused by the breakdown of the chlorophyll, a process which reveals the carotenoids, rather than by carotenoid biosynthesis, as occurs in other fruits such as apricot, mango or papaya [25]. Almost all the Musa analyzed (except dessert bananas) were found to have $\beta$-carotene levels greater than $121 \mu \mathrm{g} \cdot 100 \mathrm{~g}^{-1}$ of edible 


\begin{tabular}{|c|c|c|c|c|c|}
\hline \multirow[t]{2}{*}{ Musa types } & \multirow[t]{2}{*}{ Genomic groups } & \multirow[t]{2}{*}{ Unripe pulp color } & \multicolumn{3}{|c|}{$\alpha$-Carotene } \\
\hline & & & Unripe & Ripe & Fully ripe \\
\hline \multicolumn{6}{|l|}{ Plantains } \\
\hline Essong & $A A B$ & Orange & $3246 \pm 152 a$ & $1825 \pm 82 b$ & $1574 \pm 282 b$ \\
\hline French clair & $A A B$ & Orange & $2629 \pm 442 a$ & $2635 \pm 477 a$ & $1351 \pm 412 b$ \\
\hline French sombre & $A A B$ & Orange & $3412 \pm 769 a$ & $3201 \pm 256 \mathrm{a}$ & $2013 \pm 102 b$ \\
\hline Kelong mekintu & $A A B$ & Orange & $2997 \pm 355 a$ & $3142 \pm 484 \mathrm{a}$ & $1549 \pm 144 b$ \\
\hline Red yade & $A A B$ & Orange & $2768 \pm 396 a$ & $2802 \pm 461 \mathrm{a}$ & $2087 \pm 312 a$ \\
\hline Big ebanga & $A A B$ & Orange & $2171 \pm 963 a$ & $1926 \pm 454 \mathrm{a}$ & $1469 \pm 251$ \\
\hline Mbouroukou $n^{\circ} 1$ & $A A B$ & Orange & $4208 \pm 444 a$ & $2152 \pm 402 b$ & $1009 \pm 137 c$ \\
\hline Mbouroukou $n^{\circ} 3$ & $A A B$ & Orange & $2858 \pm 820 a$ & $2097 \pm 339 a$ & $922 \pm 82 b$ \\
\hline Btard & $A A B$ & Orange & $4188 \pm 167 a$ & $2543 \pm 246 a b$ & $1457 \pm 36 b$ \\
\hline Biya2 & $A A B$ & Orange & $2347 \pm 150 a$ & $1451 \pm 175 b$ & $451 \pm 215 c$ \\
\hline \multicolumn{6}{|l|}{ Cooking bananas } \\
\hline Dwarf kalapua & ABB & Ivory & $128 \pm 63 \mathrm{a}$ & $125 \pm 21 \mathrm{a}$ & $165 \pm 8 a$ \\
\hline Laknau & $A A B$ & Ivory & $823 \pm 265 a$ & $644 \pm 39 a$ & $627 \pm 171 \mathrm{a}$ \\
\hline Popoulou CMR & $A A B$ & Orange & $1336 \pm 404 a$ & $545 \pm 49 b$ & $595 \pm 21 b$ \\
\hline \multicolumn{6}{|l|}{ Dessert bananas } \\
\hline Foconah & $\mathrm{AAB}$ & Ivory & $517 \pm 112 \mathrm{a}$ & $196 \pm 21 c$ & $326 \pm 21 b$ \\
\hline Grande Naine & AAA & Cream & $947 \pm 90 \mathrm{a}$ & $586 \pm 168 \mathrm{a}$ & $539 \pm 17 a$ \\
\hline Yangambi km 5 & AAA & Cream & $62 \pm 5 a$ & $106 \pm 15 a$ & $44 \pm 8 a$ \\
\hline \multicolumn{6}{|l|}{ Plantain hybrids } \\
\hline CRBP 39 & AAAB & Ivory & $1593 \pm 89 a$ & $1694 \pm 207 a$ & $1784 \pm 61 \mathrm{a}$ \\
\hline CRBP 755 & AAA & Ivory & $2088 \pm 332 \mathrm{a}$ & $1961 \pm 315 a$ & $1686 \pm 184 a$ \\
\hline DS 11 & $\mathrm{AA}$ & Orange & $1710 \pm 192 c$ & $2347 \pm 61 b$ & $2984 \pm 346 a$ \\
\hline
\end{tabular}

Values are the mean of three independent determinations.

Different letters in the same line indicate significant differences $(\alpha=0.05 \%)$.

portion, which is at least 5 to 29 times the b-carotene level $\left(21 \mu \mathrm{g} \cdot 100 \mathrm{~g}^{-1}\right)$ found in bananas analyzed in the United States and the United Kingdom; although those bananas were not documented by cultivar name, they were most likely Cavendish, the primary banana cultivar marketed globally $[26,27]$. Also, some unripe plantain cultivars have greater amounts of $\beta$-carotene (700 $1200 \mu \mathrm{g} \cdot 100 \mathrm{~g}^{-1}$ of edible portion) compared with some papaya cultivars (80$410 \mu \mathrm{g} \cdot 100 \mathrm{~g}^{-1}$ ) and passion fruits (500$\left.1000 \mu \mathrm{g} \cdot 100 \mathrm{~g}^{-1}\right)[1,28-30]$. However, green leafy vegetables have very rich $\beta$ - and $\alpha$-carotene contents, but they have been shown to have poor bioavailability in relation to orange-fleshed fruits [31].
At the green mature stage, Dwarf kalapua and Popoulou CMR had no lutein; meanwhile, Yangambi $\mathrm{km} 5$ was the richest in this carotenoid pigment. French sombre, Mbouroukou $n^{\circ} 1$ and Mbouroukou $n^{\circ} 3$ exhibited the highest contents among the plantain cultivars. During the ripening of plantain cultivars, the lutein levels always decreased at stage 5 (ripe pulps), then increased considerably at stage 7 (fully ripe pulps), where the maximum value (French sombre) was observed. The lutein amounts of plantain hybrid pulps increased continuously during their ripening process, spectacular changes being noted with CRBP 755 (table III). However, compared with raw salad vegetables (Cichorium intybus, Eruca 


\begin{tabular}{|c|c|c|c|c|}
\hline \multirow[t]{2}{*}{ Musa types } & \multirow[t]{2}{*}{ Genomic groups } & \multicolumn{3}{|c|}{$\beta$-Carotene } \\
\hline & & Unripe & Ripe & Fully ripe \\
\hline \multicolumn{5}{|l|}{ Plantains } \\
\hline Essong & $A A B$ & $2025 \pm 57 a$ & $1504 \pm 67 b$ & $1105 \pm 192 c$ \\
\hline French clair & $A A B$ & $2113 \pm 360 a$ & $2218 \pm 448 a$ & $955 \pm 226 b$ \\
\hline French sombre & $\mathrm{AAB}$ & $2069 \pm 412 b$ & $2858 \pm 404 a$ & $1625 \pm 36 b$ \\
\hline Kelong mekintu & $A A B$ & $2064 \pm 200 a$ & $2157 \pm 442 \mathrm{a}$ & $1132 \pm 129 b$ \\
\hline Red Yade & $A A B$ & $1687 \pm 537 a$ & $2029 \pm 347 a$ & $1444 \pm 204 a$ \\
\hline Big Ebanga & $A A B$ & $2086 \pm 101 \mathrm{a}$ & $1760 \pm 407 a$ & $1267 \pm 198 a$ \\
\hline Mbouroukou $n^{\circ} 1$ & $A A B$ & $2843 \pm 125 a$ & $1729 \pm 324 b$ & $726 \pm 103 c$ \\
\hline Mbouroukou $n^{\circ} 3$ & $A A B$ & $1865 \pm 521 a$ & $1330 \pm 238 a$ & $580 \pm 96 b$ \\
\hline Btard & $A A B$ & $3300 \pm 137 a$ & $1988 \pm 157 a b$ & $1228 \pm 125 b$ \\
\hline Biya2 & $A A B$ & $2073 \pm 115 a$ & $1208 \pm 134 b$ & $330 \pm 150 c$ \\
\hline \multicolumn{5}{|l|}{ Cooking bananas } \\
\hline Dwarf kalapua & $A B B$ & $341 \pm 33 a$ & $344 \pm 57 a$ & $459 \pm 44 a$ \\
\hline Laknau & $A A B$ & $630 \pm 185 a$ & $339 \pm 29 a$ & $389 \pm 129 a$ \\
\hline Popoulou CMR & $A A B$ & $1125 \pm 450 \mathrm{a}$ & $587 \pm 53 a$ & $678 \pm 98 \mathrm{a}$ \\
\hline \multicolumn{5}{|l|}{ Dessert bananas } \\
\hline Foconah & $A A B$ & $365 \pm 81 a$ & $122 \pm 10 b$ & $196 \pm 25 b$ \\
\hline Grande Naine & AAA & $298 \pm 28 a$ & $253 \pm 45 a$ & $214 \pm 38 a$ \\
\hline Yangambi km 5 & AAA & $13 \pm 22 b$ & $61 \pm 8 a$ & $32 \pm 3 b$ \\
\hline \multicolumn{5}{|l|}{ Plantain hybrids } \\
\hline CRBP 39 & AAAB & $744 \pm 37 a$ & $950 \pm 119 a$ & $896 \pm 51 \mathrm{a}$ \\
\hline CRBP 755 & AAA & $1397 \pm 347 a$ & $1261 \pm 203 a$ & $1079 \pm 141 \mathrm{a}$ \\
\hline DS 11 & AA & $704 \pm 285 b$ & $1278 \pm 48 a$ & $1577 \pm 206 a$ \\
\hline
\end{tabular}

sativa, Nasturtium officinale, Lactuca sativa, Lycopersicon esculentum, Daucus carota and Capsicum annuum) studied in Brazil and in the USA, respectively, these values were too low $[32,33]$.

The levels of $\beta$ - and $\alpha$-carotenes, as well as of lutein, which were low in unripe pulps and then greatly increased in the ripe fruit, reflect the degradation of chlorophylls with a concomitant rise in carotenoids [28]. In addition, according to some studies, soil fertilization, which was applied in the experimental plot during the fruit production cycle, could be one of the factors that affected carotenoid biosynthesis in fruits
[34]. The decrease in these carotenoids, especially $\beta$ - and $\alpha$-carotenes, during ripening could be due to their degradation, which may stimulate the synthesis of other carotenoid isomers during post-harvest maturation; this phenomenon may have been enhanced by the storage conditions (at $-20{ }^{\circ} \mathrm{C}$ for more than 3 months) of the analyzed pulps.

In some matured fruits such as strawberry, red currant and the Picual olive variety, carotenoid contents decrease during ripening, as observed with many Musa cultivars studied in our study. However, this decrease did not occur in all the bananas 


\begin{tabular}{|c|c|c|c|c|}
\hline \multirow[t]{2}{*}{ Musa types } & \multirow[t]{2}{*}{ Genomic groups } & \multicolumn{3}{|c|}{ Lutein } \\
\hline & & Unripe & Ripe & Fully ripe \\
\hline \multicolumn{5}{|l|}{ Plantains } \\
\hline Essong & $A A B$ & $68 \pm 28 a$ & $22 \pm 3 b$ & $60 \pm 4 a$ \\
\hline French clair & $A A B$ & $40 \pm 6 b$ & $34 \pm 5 b$ & $307 \pm 53 \mathrm{a}$ \\
\hline French sombre & $A A B$ & $107 \pm 11 b$ & $34 \pm 7 c$ & $323 \pm 19 a$ \\
\hline Kelong mekintu & $A A B$ & $64 \pm 10 b$ & $45 \pm 12 b$ & $118 \pm 35 a$ \\
\hline Red Yade & $A A B$ & $48 \pm 7 c$ & $66 \pm 1 b$ & $80 \pm 7 \mathrm{a}$ \\
\hline Big Ebanga & $A A B$ & $68 \pm 13 b$ & $28 \pm 3 c$ & $98 \pm 3 a$ \\
\hline Mbouroukou $n^{\circ} 1$ & $A A B$ & $104 \pm 5 a$ & $23 \pm 1 b$ & $108 \pm 5 a$ \\
\hline Mbouroukou $n^{\circ} 3$ & $A A B$ & $113 \pm 6 a$ & $28 \pm 2 b$ & $131 \pm 17 \mathrm{a}$ \\
\hline Btard & $A A B$ & $44 \pm 10 b$ & $189 \pm 21 a$ & $67 \pm 16 b$ \\
\hline Biya2 & $A A B$ & $38 \pm 3 b$ & $53 \pm 4 b$ & $146 \pm 44 a$ \\
\hline \multicolumn{5}{|l|}{ Cooking bananas } \\
\hline Dwarf kalapua & ABB & Not detected & Not detected & $35 \pm 2 a$ \\
\hline Laknau & $A A B$ & $28 \pm 3 c$ & $81 \pm 22 b$ & $258 \pm 15 a$ \\
\hline Popoulou CMR & $A A B$ & ND & $133 \pm 8 a$ & $56 \pm 13 b$ \\
\hline \multicolumn{5}{|l|}{ Dessert bananas } \\
\hline Foconah & $A A B$ & $106 \pm 78 \mathrm{a}$ & $104 \pm 16 a$ & $152 \pm 6 a$ \\
\hline Grande Naine & AAA & $53 \pm 5 c$ & $183 \pm 10 a$ & $105 \pm 25 b$ \\
\hline Yangambi km 5 & AAA & $193 \pm 22 a$ & $64 \pm 9 b$ & $86 \pm 10 b$ \\
\hline \multicolumn{5}{|l|}{ Plantain hybrids } \\
\hline CRBP 39 & AAAB & $20 \pm 4 c$ & $80 \pm 7 b$ & $168 \pm 13 a$ \\
\hline CRBP 755 & AAA & $129 \pm 63 b$ & $349 \pm 33 a$ & $405 \pm 50 \mathrm{a}$ \\
\hline DS 11 & AA & $64 \pm 6 a$ & $24 \pm 1 b$ & $10 \pm 6 c$ \\
\hline
\end{tabular}

and plantains analyzed, similar to acerola fruits and the Aberquina olive variety, which showed an increase in carotenoid pigments during the ripeness stage [35].

Finally, the retinol activity equivalents (RAE) $100 \mathrm{~g}^{-1}$ of fresh weight were calculated for four Musa types, taking into account $\beta$ - and $\alpha$-carotenes, that were the only identified provitamin A carotenoids present in bananas and plantains. RAE varied considerably according to Musa types and their ripening stages. The plantain type (Mbouroukou $\mathrm{n}^{\circ} 1$ ) and the Musa hybrid (CRBP 755) exhibited the highest levels (table IV). These two plantain cultivars represent better sources of provitamin A com- pared with cooking bananas or dessert bananas. According to Englberger et al., fruits were considered as good sources of vitamin A when RAE was superior to 75 . Our results showed similar and superior RAE values compared with the best varieties analyzed in the Federated States of Micronesia [36].

Our data show that the carotenoid contents of $M u s a$ vary significantly according to their genomic groups and during the ripening process of the pulps or their stage of post-harvest maturity, which is an important criterion for banana and plantain consumers in Cameroon and neighboring countries $[17,37]$. 


$\begin{aligned} & \text { Table IV. } \\
& \text { Retinol activity equivalents (RAE) } \cdot 100 \mathrm{~g} \\
& \text { Cameroon. } \\
& \text { fresh weight of four }\end{aligned}$ Musa types collected in
\begin{tabular}{lcccc} 
Ripening stage & Mbouroukou $\mathrm{n}^{\circ} 1$ & Popoulou CMR & Grande Naine & CRBP 755 \\
\hline Unripe & 147.99 & 43.54 & 16.02 & 70.26 \\
Ripe & 78.63 & 20.19 & 9.74 & 61.01 \\
Fully ripe & 33.49 & 21.41 & 8.38 & 48.79
\end{tabular}

\section{Conclusion}

Our study showed that Musa cultivars produced in Cameroon had high carotenoid contents, although our data could have been influenced by the fruit production conditions, the harvest periods, the conservation method before analysis and the extraction and quantification procedures (exclusion of saponification for carotenoids). The interest in these staple crops as potential sources of provitamin A, whose antioxidant properties are essential in human health, was also confirmed. With their high $\beta$ - and $\alpha$-carotene levels, Bâtard and Mbouroukou n ${ }^{\circ} 1$ could be used by the Musa breeding programs for the creation and selection of new hybrids containing high carotenoid levels to enhance the nutritional status of the population. These staple foods potentially rich in provitamin A carotenoids could play a significant role in the fight against chronic infections and to prevent some cancers as well as cardiovascular diseases. Studies are currently being carried out in CARBAP (Cameroon) on some Musa varieties to confirm the significant changes in lutein, and $\beta$ - and $\alpha$-carotene contents, as well as total carotenoid levels, attributed to genetic factors, climates, soils and agricultural practices; in addition, the aim of these studies is to measure the effect of cooking on the composition of banana and plantain pulps which are always boiled, dried or fried before being eaten with food complements according to the eating habits of each region.

\section{Acknowledgments}

The authors extend sincere gratitude to CARBAP, CIRAD (Dep. PERSYST, UMR 95) and Bioversity International. They also thank Michel Ndoumbe Nkeng (IRAD) and Fabienne Ribeyre (CIRAD) for their help with the statistical analyses.

\section{References}

[1] Britton G., Liaanen-Jensen S., Pfander H., Carotenoids: Spectroscopy 1B. Basel, Switzerland, 1995.

[2] Palace V.P., Khaper N., Qin Q., Singal P., Antioxidant potentials of vitamin A and carotenoids and their relevance to heart disease, Free Radic. Biol. Med. 26 (1999) 746-761.

[3] Rock C., Carotenoids: biology and treatment, Pharmacol. Ther. 75 (1997) 185-197.

[4] Rodriguez-Amaya D.B., Carotenoïds and food preparation: the retention of provitamin A carotenoïds in prepared, processed and stored foods, OMNI/USAID, Washington DC, USA, 1997, $88 \mathrm{p}$.

[5] Astrog P., Food carotenoids and cancer prevention: An overview of current research, Tends Food Sci. Technol. 81 (1997) 406-413.

[6] Bendich A., Recent advances in clinical research involving carotenoids, Pure Appl. Chem. 66 (1994) 1017-1024.

[7] Burri B.J., Beta-carotene and human health: A review of current research, Nutr. Res. 17 (1997) 547-580.

[8] Krinsky N.I., Actions of carotenoïds in biological systems, Annu. Rev. Nutr. 13 (1993) 561-587.

[9] Mayne S.T., Beta-carotene, carotenoids, and disease prevention in humans, FASEB J. 10 (1996) 690-701.

[10] Olson J.A., Carotenoids, in: Shils M.E., Olson J.A., Shike M., Ross A.C. (Eds.), Modern nutrition in health and disease, 9th ed., Willians \& Wilkins, Baltimore, USA, 1999. 
[11] Olson J.A., Krinsky N.I., The colourful, fascinating world of the carotenoids: Important physiologic modulators, FASEB J. 9 (1995) 1547-1550.

[12] McLaren D., Frigg M., Voir et vivre. Guide pratique sur la vitamine $A$ dans la santé et la maladie, $2^{\mathrm{e}}$ éd., Groupe trav. Voir et Vivre, Bâle, Suisse, 2002.

[13] Nève J., Antioxidants alimentaires : vitamines, oligoéléments et non-nutriments, in: Roberfroid M., Aliments fonctionnels, Lavoisier (Eds.), Coll. Sci. Techn. Agroaliment., Cachan, France, 2002.

[14] Rodriguez-Amaya D.B., A guide to carotenoid analysis in foods, 1st ed., OMNI Res., USA, 2001, $64 \mathrm{p}$.

[15] Aguayo V.M., Baker S.K., Vitamin A deficiency and child survival in sub-Saharan Africa: A reappraisal of challenges and opportunities, Food Nutr. Bull. 26 (4) (2005) 348-355.

[16] Anon., The state of the world's children 2005. Childhood under threat, United Nations Children's Fund (UNICEF), New York, USA, 2005.

[17] Ngoh Newilah G., Tchango Tchango J., Fokou E., Dury S., Etoa F.X., Processing and food uses of bananas and plantains in Cameroon, Fruits 60 (4) (2005) 245-253.

[18] Dadzie B.K., Orchard J.E., Routine postharvest screening of banana and plantain hybrids: criteria and methods, INIBAP, Techn. Guidel. 2, Montpellier, France, 1997, $63 \mathrm{p}$.

[19] Burdon J.N., Moore K.G., Wainwright H., The post harvest ripening of three plantain cultivars (Musa spp., AAB group), Fruits 46 (1991) 137-143.

[20] Ngalani J.A., Tchango Tchango J., Ndoumbe Nkeng M., Noupadja P., Tomekpe K., Physicochemical changes during ripening in some plantain cultivars grown in Cameroon, Trop. Sci. 38 (1998) 42-47.

[21] Kimura M., Rodriguez-Amaya D.B., A scheme for obtaining standards and HPLC quantification of leafy vegetable carotenoids, Food Chem. 78 (2002) 389-398.

[22] Dhuique-Mayer C., Caris-Veyrat C., Ollitrault P., Curk F., Amiot M.J., Varietal and interspecific influence on micronutrient contents in citrus from the Mediterranean area, J. Agric. Food Chem. 53 (2005) 2140-2145.
[23] Anon., SAS User's Guide: Statistics, Release 8.2, SAS Institute Inc., Cary, NC, USA, 2001.

[24] Englberger L., Aalbersberg W., Ravi P., Bonnin E., Marks G.C., Fitzgerald M.H., Elymore J., Further analyses on Micronesian banana, taro, breadfruit and other foods for provitamin A carotenoids and minerals, J. Food Compos. Anal. 16 (2003) 219-236.

[25] Lusty C., Akyeampong E., Davey M.W., Ngoh Newilah G., Markham R., A staple food with nutritious appeal, Infomusa 15 (1-2) (2006) $39-43$.

[26] Holden J.M., Eldridge A.L., Beecher G.R., Buzzard I.M., Bhagwat S., Davis C.S., Douglas L.W., Gebhardt S., Haytowitz D., Schakel S., Carotenoid content of US foods: An update of the database, J. Food Compos. Anal. 12 (1999) 169-196.

[27] Holland B., Welch A.A., Unwin I.D., Buss D.H., Paul A.A., Southgate D.A.T., The composition of foods, McCance, Widdowson (Eds.), R. Soc. Chem. Minist. Agric. Fish. Food, Cambridge, UK, 1991.

[28] Alves R.E., Chitarra A.B., Chitarra M.I.F., Post harvest physiology of acerola (Malpighia emarginata D. C.) fruits: Maturation changes, respiratory activity and refrigerated storage at ambient and modified atmospheres, Acta Hortic. 370 (1995) 223-229.

[29] Wall M.M., Ascorbic acid, vitamin A, and mineral composition of banana (Musa sp.) and papaya (Carica papaya) cultivars grown in Hawaii, J. Food Compos. Anal. 19 (2006) 434-445.

[30] Brat P., Olle D., Reynes M., Brillouet J.M., The carotenoids of tropical and Mediterranean fruits and their products, in: Nakano T., Ozimek L. (Eds.), Food science and product technology, Res. Signopost, Kerala, India, 2002, pp. 187-198.

[31] De Pee S., West C.E., Permaesih D., Martuti S., Muhilal, Hautvast G.A.J.J., Orange fruit is more effective than are dark-green, leafy vegetables in increasing serum concentrations of retinol and $\beta$-carotene in schoolchildren in Indonesia, Am. J. Clin. Nutr. 68 (1998) 10581067.

[32] Niizu P.Y., Rodriguez-Amaya D.B., New data on the carotenoid composition of raw salad vegetables, J. Food Compos. Anal. 18 (2005) 739-749.

[33] Lee J.J., Crosby K.M., Pike L.M., Yoo K.S., Leskovar D.I., Impact of genetic and environmental variation on development of flavonoids 
and carotenoids in pepper (Capsicum spp.), Scientia Hortic. 106 (2005) 341-352.

[34] Gross J., Pigments in fruits, Acad. Press, London, UK, 1987.

[35] Lima V.L.A.G., Mélo E.A., Maciel M.I.S., Prazeres F.G., Musser R.S., Lima D.E.S., Total phenolic and carotenoid contents in acerola genotypes harvested at three ripening stages, Food Chem. 90 (2005) 565-568.
[36] Englberger L., Wills R.B.H., Dufficy L., Blades B., Daniells J.W., Coyne T., Carotenoid content and flesh color of selected banana cultivars growing in Australia, Food Nutr. Bull. 27 (2006) 281-291.

[37] Dury S., Bricas N., Tchango Tchango J., Temple L., Bikoi A., The determinants of urban plantain consumption in Cameroon, Food Qual. Prefer. 32 (3) (2002) 81-82.

\section{Contenido de carotenoides durante la maduración de híbridos y de cultivares de banana, cultivados en Camerún.}

Resumen - Introducción. Las bananas y los plátanos (Musa spp.) son alimentos básicos en Camerún y en los países de alrededor. Son esenciales unas estrategias basadas en la utilización de alimentos de cultivo y de consumo locales para identificar soluciones enfocadas a reducir la carencia de oligoelementos en la nutrición. Material y métodos. Para evaluar el valor alimenticio de ciertas variedades de bananas; y así participar en la elección de nuevos híbridos de Musa, se determinaron los contenidos de los carotenoides de 19 cultivares y de híbridos del tipo Musa presentes en el conjunto de material genético del CARBAP (Douala, Camerún); y esto, en tres estados de maduración post-cosecha. Se analizaron pulpas congeladas para determinar sus contenidos en $\beta$-caroteno, $\alpha$-caroteno y en luteína, mediante el método HPLC. Se calcularon los equivalentes de actividad del retinol (EAR $100 \mathrm{~g}^{-1}$ de materia fresca) para cuatro tipos representativos de Musa. Resultados y discusión. En función de los genotipos, se observaron diferencias significativas entre los cultivares de Musa; Mbouroukou n ${ }^{\circ} 1$ (tipo plátano) y el híbrido CRBP 755 presentaron los niveles de EAR más elevados [(148 y 70) EAR $100 \mathrm{~g}^{-1}$ ] comparados con los valores medidos para las bananas de postre $\left(16 \mathrm{EAR} \cdot 100 \mathrm{~g}^{-1}\right)$. Durante la maduración, aumentaron o disminuyeron las concentraciones de los carotenoides de manera significante ( $\alpha=0.05 \%$ ) de acuerdo con el tipo de banana analizado. Los altos contenidos en $\beta$-caroteno, $\alpha$-caroteno y en luteína de estos cultivares podrían contribuir a la mejora del estado alimenticio de las personas que los consumen en África central y occidental; así como al fomento de su uso en los programas de la mejora de las variedades de la banana.

Camerún / Musa / frutas / maduramiento / etapas de desarrollo / carotinoides 